\title{
Red-cockaded Woodpecker Picoides Borealis Microhabitat Characteristics and Reproductive Success in a Loblolly-Shortleaf Pine Forest
}

\author{
Douglas R. Wood ${ }^{1, *}$, L. Wesley Burger, Jr. ${ }^{1}$ and Francisco J. Vilella ${ }^{2}$ \\ ${ }^{I}$ Department of Wildlife and Fisheries, Mississippi State, Mississippi 39762, USA; ${ }^{2}$ Mississippi Cooperative Fish and \\ Wildlife Research Unit, Mississippi State, Mississippi, 39762, USA
}

\begin{abstract}
We investigated the relationship between red-cockaded woodpecker (Picoides borealis) reproductive success and microhabitat characteristics in a southeastern loblolly (Pinus taeda) and shortleaf (P. echinata) pine forest. From 1997 to 1999 , we recorded reproductive success parameters of 41 red-cockaded woodpecker groups at the Bienville National Forest, Mississippi. Microhabitat characteristics were measured for each group during the nesting season. Logistic regression identified understory vegetation height and small nesting season home range size as predictors of red-cockaded woodpecker nest attempts. Linear regression models identified several variables as predictors of red-cockaded woodpecker reproductive success including group density, reduced hardwood component, small nesting season home range size, and shorter foraging distances. Red-cockaded woodpecker reproductive success was correlated with habitat and behavioral characteristics that emphasize high quality habitat. By providing high quality foraging habitat during the nesting season, red-cockaded woodpeckers can successfully reproduce within small home ranges.
\end{abstract}

Keywords: Loblolly pine, microhabitat, Picoides borealis, red-cockaded woodpecker, reproduction, shortleaf pine.

\section{INTRODUCTION}

Red-cockaded woodpeckers (Picoides borealis; hereafter $\mathrm{RCW}$ ) are a federally-endangered species endemic to pine ecosystems of the southeastern United States [1]. Few studies have quantitatively examined RCW microhabitat selection and reproductive success within fragmented loblolly (Pinus taeda) and shortleaf (P. echinata) pine ecosystems $[2,3]$. Previous research focused on longleaf pine ( $P$. palustris) monocultures or private timber industry lands [4-6]. However, approximately $50 \%$ of RCW subpopulations on public lands are located in loblolly, shortleaf, or mixed pine forests [7]. Thus, we examined the relationship between RCW reproductive success and microhabitat characteristics within a fragmented loblolly and shortleaf pine forest.

Although numerous studies examined RCW microhabitat use, few examined the relationship between reproductive success and microhabitat characteristics $[2,3,8,9]$. The few studies that attempted to determine a causal relationship between RCW reproductive success and microhabitat characteristics produced conflicting results. RCW reproductive success was not related to the amount of suitable foraging habitat or degree of habitat fragmentation in a Florida longleaf pine forest [8]. RCW reproductive success was not related to the amount of foraging habitat provided by the RCW recovery plan $[8,10]$. Similarly, others were unable to detect a relationship between $\mathrm{RCW}$ reproductive success and microhabitat variables (i.e., stem size, frequency of large pine stems, pine basal area, or stand suitability) on private lands

*Address correspondence to this author at the Department of Biological Sciences, Southeastern Oklahoma State University, PMB 4068, 1405 N. $4^{\text {th }}$ Ave, Durant, OK 74701-0609, USA; Tel: 580-745-2272;

Fax: 580-745-7459; E-mail: dwood@se.edu
[5]. Conversely, others developed a successful discriminant function that linked the number of RCW fledglings with three microhabitat variables (i.e., number of cavities, dbh of overstory pine trees, and understory height) [11]. In Texas, RCWs had lower partial brood loss in clusters where hardwood midstory was minimal [3]. RCW foraging behavior also exhibited a preference for habitat with less hardwood midstory [2].

Our objective was to test the relationship between RCW reproductive success and microhabitat characteristics in a loblolly-shortleaf pine forest in central Mississippi. We tested the null hypotheses that microhabitat and behavioral characteristics did not influence RCW reproductive success parameters such as percent of RCW groups that attempted nesting, clutch size, number of eggs hatched, and number of young fledged per nest.

\section{MATERIALS AND METHODOLOGY}

\section{Study Area}

Bienville National Forest encompassed 72,216 ha of loblolly-shortleaf pine forest in Jasper, Newton, Scott, and Smith counties in central Mississippi. RCW areas included pine, pine-hardwood, and hardwood stands of varying age classes in a highly fragmented landscape [12]. Dominant pine species included loblolly and shortleaf pine with smaller quantities of longleaf and slash pine ( $P$. elliotii). Hardwood species such as white oak (Quercus alba), water oak $(Q . n i$ gra), willow oak ( $Q$. phellos), southern red oak (Q.falcata), mockernut hickory (Carya tomentosa), and sweetgum (Liquidambar styraciflua) were also present but in lower densities and in riparian areas. With a range of 94-107 active RCW groups, Bienville National Forest contained the largest subpopulation of RCWs in Mississippi [12]. 


\section{Methods}

We randomly selected, without replacement, a subsample of all RCW groups at Bienville National Forest each year for visual observations (1997 [ $n=15], 1998$ [ $n=14]), 1999$ [ $n=$ 12] [11]. Five-hr visual observation periods were performed on selected groups for one year beginning in January and concluding in December annually [8]. Visual observation periods were performed sequentially by group throughout the year to approximate equal effort [10]. Visual observation periods began at first light and concluded five hrs after RCWs were first observed. Each visual observation period was subdivided into 6-min periods which consisted of a 1min observation period followed by a 5-min waiting period [13]. We used a 6-min period to ensure that all habitat types used by RCWs were detected. We defined the group as the sampling unit and selected one RCW from the group during the visual observation period and recorded all locations of that individual $\mathrm{RCW}$ during the 1-min observation period [14].

We quantified microhabitat characteristics of RCW foraging locations using a modified bird-centered location method $[15,16]$. Plots were centered on trees selected by RCWs during visual observation periods. For each RCW group, we sub-sampled for microhabitat variables at every fifth location throughout the year. Vegetation plots were categorized as nesting depending upon nest initiation and fledging dates for each group. Microhabitat characteristics were quantified inside vegetation sampling plots $[17-19,10]$ (Table 1).

We recorded whether nesting was attempted, clutch size, number of eggs hatched, and number of young fledged per nest for each RCW group. We used a Treetop Peeper Scope (Sandpiper Technologies Inc., Manteca, California), to obtain data on presence/absence of an incubating adult, clutch size, and number of eggs hatched. We counted fledglings at the time they left the nest cavity.

For the nesting attempted model, the response variable was binomial (attempted or not attempted), therefore we performed logistic regression using PROC LOGISTIC [20]. For other reproductive parameter models, response variables were continuous; therefore we performed linear regression using PROC REG [20]. For all models, multicollinearity was detected by diagnostic procedures [20]. Therefore, we specified the STEPWISE model selection option which provided reduced models for regression analyses. Multicollinearity problems were not detected in the reduced models during subsequent regression analyses. Following model selection, we ran separate regressions for each nest stage parameter $($ alpha $=0.10)$.

\section{RESULTS}

\section{Reproductive Success and Microhabitat Characteristics}

Seventy percent of RCW groups attempted nesting. RCWs averaged 3.2 eggs/nest, 2.8 eggs hatched/nest, and 2.0 young fledged/nest. Table 2 includes mean values \pm standard errors for nesting season microhabitat variables and other behavioral variables.
Table 1. Microhabitat and behavioral variables sampled at Red-cockaded Woodpecker foraging locations at Bienville National Forest, Mississippi 1997-1999.

\begin{tabular}{|c|c|}
\hline Variable & Definition \\
\hline DENSIOT & Mean percent canopy cover at tree resolution \\
\hline DENSIOF & Mean percent canopy cover at stand resolution \\
\hline B1 & Mean percent horizontal obstruction $(2.0-2.5 \mathrm{~m})$ \\
\hline B2 & Mean percent horizontal obstruction $(1.5-2.0 \mathrm{~m})$ \\
\hline B3 & Mean percent horizontal obstruction $(1.0-1.5 \mathrm{~m})$ \\
\hline B4 & Mean percent horizontal obstruction $(0.5-1.0 \mathrm{~m})$ \\
\hline GROUND & Mean percent horizontal obstruction $(0.0-0.5 \mathrm{~m})$ \\
\hline MIDHGT & Mean mid-story canopy height (m) \\
\hline CANHGT & Mean dominant canopy height (m) \\
\hline TOTSTEMS & Mean number of stems/ha \\
\hline PSTEMS & Mean number of pine stems/ha \\
\hline HSTEMS & Mean number of hardwood stems/ha \\
\hline P35HA & Mean number of pine stems $7.6-12.7 \mathrm{~cm} / \mathrm{ha}$ \\
\hline P610HA & Mean number of pine stems $15.2-25.4 \mathrm{~cm} / \mathrm{ha}$ \\
\hline P11HA & Mean number of pine stems $\geq 27.9 \mathrm{~cm} / \mathrm{ha}$ \\
\hline H35HA & Mean number of hardwood stems $7.6-12.7 \mathrm{~cm} / \mathrm{ha}$ \\
\hline H610HA & Mean number of hardwood stems $15.2-24.5 \mathrm{~cm} / \mathrm{ha}$ \\
\hline H11HA & Mean number of hardwood stems $\geq 27.9 \mathrm{~cm} / \mathrm{ha}$ \\
\hline PSNAG & Mean number of pine snags/ha \\
\hline HSNAG & Mean number of hardwood snags/ha \\
\hline BAP35 & Mean basal area of pine stems $7.6-12.7 \mathrm{~cm}\left(\mathrm{~m}^{2} / \mathrm{ha}\right)$ \\
\hline BAP610 & Mean basal area of pine stems $15.2-25.4 \mathrm{~cm}\left(\mathrm{~m}^{2} / \mathrm{ha}\right)$ \\
\hline BAP11 & Mean basal area of pine stems $\geq 27.9 \mathrm{~cm}\left(\mathrm{~m}^{2} / \mathrm{ha}\right)$ \\
\hline BAH35 & Mean basal area of hardwood stems $7.6-12.7 \mathrm{~cm}\left(\mathrm{~m}^{2} / \mathrm{ha}\right)$ \\
\hline BAH610 & Mean basal area of hardwood stems $15.2-24.4 \mathrm{~cm}\left(\mathrm{~m}^{2} / \mathrm{ha}\right)$ \\
\hline BAH11 & Mean basal area of hardwood stems $\geq 27.9 \mathrm{~cm}\left(\mathrm{~m}^{2} / \mathrm{ha}\right)$ \\
\hline MID & Mean number of mid-story stems/ha \\
\hline CAN & Mean number of dominant canopy stems/ha \\
\hline TOTSNG & Mean number of snags/ha \\
\hline HRA & Mean annual home range size (ha) \\
\hline HRNN & Mean non-nesting season home range size (ha) \\
\hline HRN & Mean nesting season home range size (ha) \\
\hline BURN & Growing seasons since last prescribed burn (yrs) \\
\hline DENSITY & $\begin{array}{l}\text { Rank of RCW group density }(1=\text { low; } 2=\text { medium; } \\
3=\text { high })\end{array}$ \\
\hline FODISTA & Farthest foraging location from brood tree annually $(\mathrm{m})$ \\
\hline FODISTNN & $\begin{array}{l}\text { Farthest foraging location from brood tree } \\
\text { (non-nesting season) (m) }\end{array}$ \\
\hline FODISTN & $\begin{array}{l}\text { Farthest foraging location from brood tree } \\
\text { (nesting season) }(\mathrm{m})\end{array}$ \\
\hline
\end{tabular}


Table 2. Descriptive statistics of microhabitat and behavioral variables measured at Red-cockaded Woodpecker foraging locations at Bienville National Forest, Mississippi (1997-1999).

\begin{tabular}{|c|c|c|c|}
\hline Variable & Mean & SE & Range \\
\hline DENSIOT & 93.6 & 0.4 & $87-97$ \\
\hline DENSIOF & 86.6 & 0.9 & $68-93$ \\
\hline B1 & 49.8 & 3.0 & $12-82$ \\
\hline B2 & 55.4 & 3.2 & $12-86$ \\
\hline B3 & 62.8 & 3.3 & $13-92$ \\
\hline B4 & 70.9 & 3.1 & $17-96$ \\
\hline GROUND & 84.3 & 2.0 & $46-99$ \\
\hline MIDHGT & 10.6 & 0.5 & $22-64$ \\
\hline CANHGT & 26.4 & 0.2 & $68-95$ \\
\hline TOTSTEMS & 364.5 & 17.5 & $155-890$ \\
\hline PHA & 228.1 & 11.3 & $128-470$ \\
\hline HHA & 143.6 & 10.4 & $27-420$ \\
\hline P35HA & 67.4 & 8.7 & $5-280$ \\
\hline P610HA & 42.7 & 3.8 & $2-109$ \\
\hline P11HA & 118.1 & 4.4 & $75-184$ \\
\hline H35HA & 84.9 & 6.9 & $13-280$ \\
\hline H610HA & 45.4 & 3.9 & $10-115$ \\
\hline H11HA & 12.2 & 2.0 & $0-70$ \\
\hline PSNAG & 6.4 & 0.8 & $0-19$ \\
\hline HSNAG & 28.3 & 4.2 & $2-99$ \\
\hline BAP35 & 4.7 & 1.2 & $0-35$ \\
\hline BAP610 & 7.7 & 1.6 & $0-59$ \\
\hline BAP11 & 154.8 & 15.5 & $53-632$ \\
\hline BAH35 & 6.5 & 2.1 & $0-69$ \\
\hline BAH610 & 6.9 & 1.0 & $0-24$ \\
\hline BAH11 & 4.6 & 1.6 & $0-61$ \\
\hline MID & 227.2 & 16.6 & $35-665$ \\
\hline CAN & 140.1 & 6.0 & $75-225$ \\
\hline TOT & 35.5 & 4.2 & $5-107$ \\
\hline BURN & 4.7 & 0.7 & $1-8$ \\
\hline HRA & 54.6 & 6.0 & $14-97$ \\
\hline HRNN & 42.9 & 6.4 & $10-94$ \\
\hline HRN & 24.0 & 3.0 & $7-45$ \\
\hline DENSITY & 2.1 & 0.2 & $1-3$ \\
\hline FODISTA & 783.2 & 57.9 & $280-1224$ \\
\hline FODISTNN & 739.1 & 62.9 & $400-1224$ \\
\hline FODISTN & 518.0 & 54.3 & $280-942$ \\
\hline
\end{tabular}

\section{Nest Attempts}

Mean percentage horizontal obstruction $(2.0-2.5 \mathrm{~m})$ $\left(\chi_{1}^{2}=4.47, P=0.04\right)$ and mean nesting season home range were retained in the final logistic regression model $\left(\chi_{1}{ }^{2}=\right.$ 2.86, $P=0.09$ ). The model correctly classified $87 \%$ (33 of 38) of RCW nest attempts; however, the model only correctly classified 33\% (1 of 3) of RCW groups that did not attempt nesting. Nest attempts were associated positively with mean percentage horizontal obstruction $(2.0-2.5 \mathrm{~m})$ (Coefficient $=0.136, \mathrm{SE}=0.07$ ) and negatively associated with mean nesting season home range (Coefficient $=-0.113$, $\mathrm{SE}=0.07)$.

\section{Clutch Size}

A five variable model (mean percentage canopy cover at tree resolution, mean percentage horizontal obstruction [2.0$2.5 \mathrm{~m}$ ], mean mid-story canopy height, rank of RCW group density, and farthest foraging location from the brood tree annually) explained more variation than a model with no variables (i.e., intercept only) $\left(F_{5,22}=5.35, P<0.001 ; \mathrm{R}^{2}\right.$ adj $=0.44)$. Model selection procedures removed one variable, mean mid-story canopy height, from the final regression model $\left(t_{22}=1.69, P=0.11\right)$. After model selection (Table 3 ), four variables remained in the final regression model including: mean percentage canopy cover at tree resolution $\left(t_{22}=\right.$ 2.45, $P=0.02)$, mean percentage horizontal obstruction $(2.0-2.5 \mathrm{~m})\left(t_{22}=2.19, P=0.04\right)$, rank of RCW group density $\left(t_{22}=4.25, P<0.001\right)$, and farthest foraging location from the brood tree annually $\left(t_{22}=-2.34, P=0.03\right)$.

\section{Number Hatched}

Six variables were entered into the regression model $\left(F_{6,25}=6.94, P<0.001 ; \mathrm{R}^{2}\right.$ adj $\left.=0.54\right)$. All variables remained in the final regression model (Table 3 ) including: mean number of hardwood stems $\geq 27.9 \mathrm{~cm} / \mathrm{ha} \quad\left(t_{22}=-3.40\right.$, $P<0.001)$, mean basal area of hardwood stems $15.2-24.4 \mathrm{~cm}$ $\mathrm{m}^{2} /$ ha $\left(t_{22}=-3.82, P<0.001\right)$, mean annual home range size $\left(t_{22}=-2.65, P=0.01\right)$, rank of RCW group density $\left(t_{22}=3.17, P<0.001\right)$, farthest foraging location from brood tree [nesting season] $\left(t_{22}=-2.94, P=0.01\right)$ and mean nonnesting season home range size $\left(t_{22}=-1.95, P=0.06\right)$.

\section{Number Fledged}

Five variables were entered into the regression model (rank of RCW group density, mean nesting season home range size, mean number of midstory stems/ha, mean number of hardwood snags/ha, and mean percentage horizontal obstruction $[1.0-1.5 \mathrm{~m}])\left(F_{5,31}=4.53, P<0.001 ; \mathrm{R}_{\text {adj }}^{2}=\right.$ 0.33). Model selection procedures dropped two variables, mean nesting season home range size $\left(t_{22}=-1.69, P=0.11\right)$ and mean percentage horizontal obstruction $(1.0-1.5 \mathrm{~m})\left(t_{22}\right.$ $=-1.58, P=0.13)$ from the final model. Three variables remained in the final regression model (Table 3), mean number of midstory stems/ha $\left(t_{22}=-2.33, P=0.03\right)$, mean number of hardwood snags/ha $\left(t_{22}=-2.36, P=0.03\right)$, and rank of RCW group density $\left(t_{22}=1.89, P=0.07\right)$. 
Table 3. Coefficients \pm standard errors (SE) associated with significant variables from linear regression models of Red-cockaded Woodpecker microhabitat and behavioral characteristics compared to reproductive success parameters at Bienville National Forest, Mississippi 1997-1999.

\begin{tabular}{|c|c|c|c|}
\hline $\begin{array}{l}\text { Reproductive } \\
\text { Parameter }\end{array}$ & Variable & Coefficient & $\pm \mathrm{SE}$ \\
\hline \multicolumn{4}{|l|}{ Clutch size } \\
\hline & Intercept & -12.4 & 5.97 \\
\hline & DENSITY & +0.514 & 0.12 \\
\hline & B1 & +0.012 & 0.01 \\
\hline & FODISTA & -0.001 & $<0.001$ \\
\hline & DENSIOT & +0.142 & 0.06 \\
\hline \multicolumn{4}{|l|}{$\begin{array}{l}\text { Number } \\
\text { hatched }\end{array}$} \\
\hline & Intercept & +2.61 & 0.27 \\
\hline & H11HA & -0.02 & 0.01 \\
\hline & BAH610 & -0.03 & 0.01 \\
\hline & HRA & +0.012 & 0.01 \\
\hline & DENSITY & +0.297 & 0.09 \\
\hline & FODISTN & -0.001 & $<0.001$ \\
\hline & HRNN & -0.013 & 0.01 \\
\hline \multicolumn{4}{|l|}{$\begin{array}{l}\text { Number } \\
\text { fledged }\end{array}$} \\
\hline & Intercept & +3.54 & 0.7 \\
\hline & DENSITY & +0.226 & 0.12 \\
\hline & MID & -0.003 & $<0.001$ \\
\hline & HSNAG & -0.014 & 0.01 \\
\hline
\end{tabular}

\section{DISCUSSION}

\section{Nest Attempts}

Two variables, mean percentage horizontal obstruction $(2.0-2.5 \mathrm{~m})$ and mean nesting season home range were useful in predicting RCW nest attempts. RCW nest attempts were related positively with increased values of horizontal obstruction (i.e., understory vegetation density). Understory vegetation at the Bienville NF consisted mainly of herbaceous vegetation, vines, and hardwood shrubs and saplings [12]. Other researchers suggested that height of understory vegetation may affect production of insect prey used by foraging RCWs [5]. Although we did not sample potential prey availability and their habitat associations, several studies have examined RCW prey selection. In South Carolina, adult RCWs provisioned chicks with several insect species associated with understory habitats [21]. Similarly, other researchers determined that a significant proportion of the macroarthropod biomass available to foraging $\mathrm{RCWs}$ originate in the soil and vegetative litter on the forest floor [22]. There- fore, the structure and composition of the understory may have a significant impact on RCW fitness [23,24].

RCW nest attempts were negatively associated with RCW nesting season home range size. Thus, RCW groups that did not attempt nesting had larger mean nesting season home ranges than RCW groups that did nest. This suggests that RCW groups located in areas with better habitat quality have smaller home ranges than RCW groups in poor quality habitats with larger home ranges [12]. RCW groups that fly shorter distances to obtain food for nestlings would retain a competitive advantage over groups that fly longer distances to obtain the same resources $[9,25]$.

\section{Clutch Size}

RCW clutch size was positively associated with understory vegetation height and increasing RCW group density. The strong positive relationship of canopy cover reflects the presence of a high stocking density of mature pines in the cluster areas. No relationship between RCW group density and provisioning rates of nestlings was reported in a Texas RCW subpopulation; however, clutch size was not included as a dependent variable [26]. Conversely, RCW clutch size was related inversely with farthest foraging distance from the brood tree (i.e., RCW groups with larger clutch sizes foraged closer to the brood tree than RCW groups with smaller clutch sizes). This result suggests that RCW groups with smaller annual foraging ranges were able to lay larger clutches [9,25]. In Louisiana, other researchers reported mean seasonal foraging distances for RCW groups in Louisiana; however, they did not attempt to relate measures of $\mathrm{RCW}$ reproductive success with foraging distance [27].

\section{Number Hatched}

The number of hatchlings was positively related to increasing RCW group density. The negative relationship with presence of hardwood stem density and basal area was similar to other studies of RCW habitat selection [25,27,28]. The inclusion of mean annual and non-nesting season home range size suggests that hatching success may be related to habitat quality and group density. In areas with increased $\mathrm{RCW}$ group densities, RCW home ranges should be smaller than RCW groups in areas of decreased group density due to territoriality and competition. This also suggests that RCW groups occupying better habitats require less space to meet the energetic requirements of nestlings and adults. The negative relationship with foraging distance in the model supports this hypothesis. This relationship has been documented in paruline warblers [29], belted kingfisher (Megaceryle alcyon) [30], and Lapland longspurs (Calcarius lapponicus) [31].

\section{Number Fledged}

The number of fledglings was positively associated with increasing RCW group density [26,32]. However, RCW fledgling production was negatively associated with mean number of midstory stems/ha and hardwood snags/ha. This result suggested that fledgling numbers increased with decreasing hardwood stem densities. On private timber lands, no relationship between number of fledglings/nest and hard- 
wood stem densities or basal area within $400-800 \mathrm{~m}$ of $\mathrm{RCW}$ brood trees was detected [5]. In a mixed pine forest in Louisiana, RCWs selected foraging sites with low hardwood basal areas during the nesting and non-nesting season, although they did not relate microhabitat selection with RCW reproductive success [27]. Similarly, others reported that RCWs selected foraging stands with low hardwood stem densities and high pine densities, but did not relate habitat selection to reproductive success [8]. In Arkansas, RCWs selected foraging sites with fewer hardwoods $(<22.9 \mathrm{~cm})$, but no attempt was made to relate habitat components with reproductive success [25]. Other studies have examined RCW microhabitat selection and fledgling production; however hardwood components were not included in analysis $[4,11]$.

\section{Microhabitat and Reproductive Success}

Numerous descriptive studies have examined RCW microhabitat selection [33-38], although none of those studies examined the role of microhabitat selection and RCW fitness measures. Several studies examined RCW reproductive success and microhabitat selection; however, these studies produced conflicting results. In southwestern Georgia, RCWs in old-growth longleaf pine forest demonstrated greater reproductive success, than RCWs in modified landscapes with lower habitat quality [39]. Others reported a relationship between RCW reproductive success and indicators of habitat quality (i.e., microhabitat variables) including number of cavities present, understory height, and dbh of overstory pine trees in North Carolina [11]. Using microhabitat variables, a discriminant function was developed that was $80 \%$ successful at classifying successful and unsuccessful RCW groups [11]. In a Florida longleaf pine forest, a positive relationship between RCW reproductive success measures and microhabitat variables was reported [32]. The number of RCW fledglings produced was inversely related to density of pine trees $>25 \mathrm{~cm}$ dbh and pine basal area (i.e., increased densities of large pine stems and large pine basal areas had a negative impact on RCW reproductive success) [32].

Conversely, several studies reported insignificant relationships between RCW reproductive success and microhabitat variables. In a Florida longleaf pine forest, researchers were unable to link RCW reproductive success with microhabitat variables associated with RCW foraging habitat management guidelines [4]. On private timber lands in Louisiana, no relationship between microhabitat variables and the presence of eggs or fledglings produced was detected in univariate analyses or included in predictive models [5].

RCW reproductive success was correlated with habitat and behavioral characteristics that emphasize high quality habitat. By providing high quality foraging habitat during the nesting season, RCWs can successfully reproduce within small home ranges (i.e., increase group density). This would allow more RCWs to make greater contributions to population recruitment and species recovery.

\section{CONFLICT OF INTEREST}

The authors confirm that this article content has no conflict of interest.

\section{ACKNOWLEDGEMENTS}

Thank you to S. Samano, M. Taquino, C. Reynolds, E. Grant, J. Kelly, R. Chambers, D. Harrington, J. Altman, C. McRae, R. Hamrick, N. Winstead, W. Bailey, S. Tedford, K. Swanson, M. Proett, R. Carlson, S. Smith, and T. Sullivan for their tireless efforts under difficult field conditions. We thank the U.S. Forest Service, National Council of the Paper Industry for Air and Stream Improvement, the Forest and Wildlife Research Center at Mississippi State University, and the Mississippi Cooperative Fish and Wildlife Research Unit for financial support for this research. We appreciate the Mississippi Department of Wildlife, Fisheries, and Parks for logistical support. Any use of trade, firm, or product names is for descriptive purposes only and does not imply endorsement by the U.S. Government.

\section{PATIENT'S CONSENT}

Declared none.

\section{REFERENCES}

[1] Jackson JA. Red-cockaded Woodpecker (Picoides borealis). In: Poole A, Gill F, Eds. The Birds of North America, No. 85. Philadelphia, Pennsylvania: The Birds of North America, Inc., 1994; pp. 1-20.

[2] Rudolph DC, Conner RN, Schaefer RR. Red-cockaded Woodpecker foraging behavior in relation to midstory vegetation. Wilson Bull 2002; 235-42.

[3] McCormick JR, Conner RN, Burt DB, Saenz D. Influence of habitat and number of nestlings on partial brood loss in Red-cockaded Woodpeckers. In: Costa, R, Daniels, SJ, Eds. Red-cockaded woodpecker: Road to Recovery, Blaine, Washington: Hancock House Publication 2004; pp. 624-9.

[4] Beyer Jr. DE, Costa R, Hooper RG, Hess CA. Habitat quality and reproduction of red-cockaded woodpecker groups in Florida. J Wildlife Manage 1996; 60: 826-35.

[5] Wigley TB, Sweeney SW, Sweeney JR. Habitat attributes and reproduction of red-cockaded woodpeckers in intensively managed forests. Wildlife Soc Bull 1999; 27: 801-9.

[6] Zwicker SM, Walters JR. Selection of pines for foraging by redcockaded woodpeckers. J Wildlife Manage 1999; 63: 843-52.

[7] U.S Department of the Interior. Red-cockaded woodpecker recovery plan. U. S Fish and Wildlife Service, Southeast Region, Atlanta, Georgia, 2003.

[8] Hooper RG, Harlow RF. Forest stands selected by foraging redcockaded woodpeckers. U. S Forest Service Research Paper 1986; SE-259: pp. 1-10.

[9] DeLotelle RS, Epting RJ, Newman JR. Habitat use and territory characteristics of red-cockaded woodpeckers in central Florida. Wilson Bull 1987; 99: 202-17.

[10] U.S Department of the Interior. Red-cockaded woodpecker recovery plan. U. S Fish and Wildlife Service, Southeast Region, Atlanta, Georgia, 1985.

[11] Davenport DE, Lancia RA, Walters JR, Doerr PD. Red-cockaded woodpeckers: a relationship between reproductive fitness and habitat in the North Carolina Sandhills. Wildlife Soc Bull 2000; 28: 426-34.

[12] Wood DR. Multi-resolution assessment of the foraging and reproductive ecology of red-cockaded woodpeckers in a Mississippi loblolly-shortleaf pine forest. Ph.D. dissertation. Starkville, Mississippi: Mississippi State University, 2001.

[13] Hooper RG, Niles LJ, Harlow RF, Wood GW. Home ranges of redcockaded woodpeckers in coastal South Carolina. Auk 1982; 99: 675-82.

[14] Wood DR, Burger Jr. LW, Vilella FJ. Red-cockaded woodpecker (Picoides borealis) behavioral patterns in a Mississippi loblollyshortleaf pine forest. J Miss Acad Sci 2005; 50: 168-76.

[15] James FC, Shugart HH. A quantitative method of habitat description. Audubon Field Notes 1970; 24: 727-36. 
[16] Larson DL, Bock CE. Determining avian habitat preference by bird-centered vegetation sampling. In: Verner J, Morrison M, Ralph C, Eds. Wildlife 2000: Modeling habitat relationships of terrestrial vertebrates, Madison, Wisconsin: The University of Wisconsin Press 1986; pp. 37-43.

[17] Lemmon PE. A new instrument for measuring forest over story density. J For 1957; 55: 667-9.

[18] Nudds TD. Quantifying the vegetative structure of wildlife cover. Wildlife Soc Bull 1977; 5:113-7.

[19] U. S Forest Service. Final environmental impact statement for the management of the red-cockaded woodpecker and its habitat on national forests in the southern region. U. S For Serv Manage Bull R8-MB 73 1995; 3: 1-407.

[20] SAS Institute. SAS/STAT ${ }^{\circledR}$ user's guide. Version 7. SAS Institute, Cary, North Carolina 1998.

[21] Harlow RF, Lennartz MR. Foods of nestling red-cockaded woodpeckers in coastal South Carolina. Auk 1977; 94: 376-7.

[22] Hanula JL, Franzreb KE. Source, distribution and abundance of macroarthropods on the bark of longleaf pine: potential prey of the red-cockaded woodpecker. For Ecol Manage 1998; 102: 89-102.

[23] Franzreb KE, Hanula JL. Evaluation of photographic devices to determine nestling diet of the endangered red-cockaded woodpecker. J Field Ornithol 1995; 66: 253-9.

[24] New KC, Hanula JL. Effect of time elapsed after prescribed burning in longleaf pine stands on potential prey of the red-cockaded woodpecker. S J Appl For 1998; 22: 175-83.

[25] Doster RH, James DA. Home range size and foraging habitat of red-cockaded woodpeckers in the Ouachita Mountains of Arkansas. Wilson Bull 1998; 110: 110-7.

[26] Conner RN, Rudolph DC, Schaeffer RR, Saenz D, Shackleford CE. Relationships among red-cockaded woodpecker group density, nestling provisioning rates, and habitat. Wilson Bull 1999; 111: 494-8.

[27] Jones CM, Hunt HE. Foraging habitat of the red-cockaded woodpecker on the D'Arbonne National Wildlife Refuge, Louisiana. J Field Ornithol 1996; 67: 511-8.

[28] Bradshaw DS. Habitat use by a relict population of red-cockaded woodpeckers in southeastern Virginia. In: Kulhavy D, Hooper R, Costa R, Eds. Red-cockaded Woodpecker recovery, ecology and management. Nacogdoches, Texas: Center for Applied Studies in Forestry, College of Forestry, Stephen F. Austin State University 1995; pp.482-8.
[29] Morse DH. Variables affecting the density and territory size of breeding spruce-woods warblers. Ecology 1976; 57: 290-301.

[30] Davis JD. Territory size in Megaceryle alcyon along a stream habitat. Auk 1982; 99: 353-62.

[31] Seastedt TR, MacLean SF. Territory size and composition in relation to resource abundance in Lapland longspurs breeding in arctic Alaska. Auk 1979; 131-42.

[32] Hardesty JL, Lucas KE, Percival HF. Ecological correlates of redcockaded woodpecker (Picoides borealis) foraging preference, habitat use and home range size in northwest Florida (Eglin Air Force Base). Florida Coop. University of Florida, Gainesville. Fish and Wildlife Res Unit 1997; pp. 1-80.

[33] Morse DH. Habitat utilization of the red-cockaded woodpecker during the winter. Auk 1972; 89: 429-35.

[34] Sherill DM, Case VM. Winter home range of 4 clans of redcockaded woodpeckers in the Carolina Sandhills. Wilson Bull 1980; 92: 369-75.

[35] Locke BA, Conner RN, Kroll JC. Factors influencing colony site selection by red-cockaded woodpeckers. In: Wood D, Ed. Redcockaded Woodpecker Symposium II. Tallahassee, Florida: Florida Game and Freshwater Fish Commission, 1983; pp. 46-50.

[36] Wood DA. Foraging and colony habitat characteristics of the redcockaded woodpecker in Oklahoma. In: Wood D, Ed. Redcockaded Woodpecker Symposium II. Tallahassee, Florida: Florida Game and Freshwater Fish Commission, 1983; pp. 51-8.

[37] Epting RJ, DeLotelle RS, Beaty T. Red-cockaded woodpecker territory and habitat use in Georgia and Florida. In: Kulhavy D, Hooper R, Costa R, Eds. Red-cockaded Woodpecker recovery, ecology and management. Nacogdoches, Texas: Center for Applied Studies in Forestry, College of Forestry, Stephen F. Austin State University, 1995; pp. 270-6.

[38] Bowman RD, Leonard DL, Bakus LK, et al. Demography and habitat characteristics of the red-cockaded woodpecker (Picoides borealis) at the Avon Park Air Force Range. Final Report 1994 1998 Contract F0862-97-D0015. Lake Placid, Florida: Archbold Biological Station, 1980

[39] Engstrom RT, Sanders FJ. Red-cockaded woodpecker foraging ecology in an old-growth longleaf pine forest. Wilson Bulletin 1997; 109: 203-17.

(C) Wood et al.; Licensee Bentham Open.

This is an open access article licensed under the terms of the Creative Commons Attribution Non-Commercial License (http://creativecommons.org/licenses/by-nc/3.0/) which permits unrestricted, non-commercial use, distribution and reproduction in any medium, provided the work is properly cited. 